\title{
スライス牛肉の $\mathrm{pH}$ 值，細菌数，メトミオグロビン生成量 および脂質酸化に及ぼす真空とフラッシュガス 置換包装の影響
}

\author{
岡山高秀* ・六車三治男 ${ }^{* *} \cdot$ 村上新一*** • 山田裕一*** \\ Effect of Two Modified Atmosphere Packaging Systems on $\mathrm{pH}$ Value, \\ Microbial Growth, Metmyoglobin Formation and Lipid \\ Oxidation of Thin Sliced Beef \\ (Studies on Modified Atmosphere Packaging of Thin Sliced Beef Part I) \\ Takahide Okayama*, Michio Muguruma ${ }^{* *}$, Shinichi Murakami** \\ and Hirokazu Y AMADA ${ }^{* * *}$ \\ * Faculty of Agriculture, Kobe University, 1-1 Rokkodai-cho, Nada-ku, Kobe 657 \\ ** Faculty of Agriculture, Kyushu University, 6-10-1, Hakozaki, Higashi-ku, Fukuoka 812 \\ *** Showa Denko K. K., 13-9 Shiba Daimon 1-Chome, Minato-ku, Tokyo 105
}

This study was conducted to determine the effect of two modified atmosphere packaging systems with and without vacuum treatment on storage quality characteristic of thin sliced beef stored at $5^{\circ} \mathrm{C}$. Thin sliced beef was packaged in atmospheres of : (A) air without gas flush treatment (control), (B) $20 \% \mathrm{CO}_{2}+80 \% \mathrm{O}_{2}$ after vacuum treatment and (C) $20 \% \mathrm{CO}_{2}+80 \% \mathrm{O}_{2}$ without vacuum treatment. After $0,2,4,6$ and 8 days of storage, each sample was evaluated for $\mathrm{pH}$ value, microbial growth, metmyoglobin (MetMb) formation, lipid oxidation (TBA number). The pH value of the control was significantly higher than those of (B) and (C) samples after 8 days of storage. The viable and psychrotrophic bacterial counts and the number of coliforms of (B) and (C) samples were less than those of the control during storage. The control, $(B)$ and $(C)$ samples attained a MetMb level of $20 \%$ after 3,5 and 6 days of storage, respectively. At 6 days of storage, MetMb formation of (C) sample was significantly lower than that of the control, but the difference in the results of the control and (B) sample could not be regarded as significant. Although the TBA numbers of (B) and (C) samples were higher than those of the control, both samples maintained a TBA number of 3.0 even after 6 days of storage. These results suggested that the differences in $\mathrm{pH}$ value, microbial growth, lipid oxidation of vacuum between samples with and without vacuum treatment were not recognized significantly, but the rate of $\mathrm{MetMb}$ formation may be different between them during storage.

(Received Aug. 3, 1994)

近年，包装材料と包装機械の発展に伴い，わが国にお いてもスライス牛肉のガス置換包装商品が次第に定着化
しつつある. ガス置換包装したスライス牛肉商品の賞味 期間 (Shelf life) の延長がかなり確実に認められ，さら

\footnotetext{
†スライス牛肉のガス置換包装に関する研究（第 1 報）

* 神戸大学農学部 (T657 神戸市灌区六甲台町 1-1)

** 九州大学農学部 (干812 福岡市東区箱崎 6-10-1)

*** 昭和電工(株)（干105 東京都港区芝大門 1-13-9）
} 
にスーパーマーケットのセントラル包装方式が進むにつ れ，今後益々普及するすの音) と期待されている.

牛肉のガス置換包装に関する多いの研究から，色調に 関して，高婊度の酸素条件下においてはオキシミオグロ ビン $\left(\mathrm{MbO}_{2}\right)$ の鮮赤色の状態を維持することにより, 褐 色のメトミオグロビン (MetMb) の生成を抑制し，良い

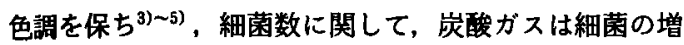
殖を抑制する効果を有し，特にグラム陰性菌に対する静 菌効果の強いことが報告苜 ${ }^{-8)}$ されている. 現在, 使用さ れているガス㯰換包装の方法には，次の二つの方法があ る.すなわち，ガス置換前に一度チャンバー内の空気を 脱気した後，装着されたノズルから目的のガスを充填す る, 真空ガス圆換包装と，巻取フィルムより袋を作り， 陚料を入れ目的のガスを吹き込みながら空気を排除し ヒートシールする，フラッシュガス置換包装である，上 記の二つの異なったガス置換方法で包装した試料の種々 の変化を比较・検討した報告はほとんどない，今日，市 場に流通しているコンシューマーパックの条件下で, し かも，わが国での販売形態に多い非常に薄いスライス牛 肉についてのガス置换包装に関する報告は非常に少な $\left(^{9910)}\right.$. 本報告の目的は，一般市場ですでに流通している のと同一のガス置換包装条件下で， スライス牛肉の $\mathrm{pH}$ 值, 細菌数, メトミオグロビン生成量および脂質酸化に 及ぼす二っの異なったガス置換の方法である，真空とフ ラッシュガス置換包装の影暨につき検討することであ る.

実 験 方 法

\section{1. 実殹材料および包恠}

屠殺後 3 日間常法で冷却したホルスタイン種去勢牛 (約 22 力月秢) 加ら腿部位（約 $8.5 \mathrm{~kg}$ ）を採取し，クレハ
ロンフィルムで真空包装し， $1^{\circ} \mathrm{C}$ で 8 日間就成した後, 厚さ $2 \mathrm{~mm}$ にスライスした，得られた試料約 $120 \mathrm{~g}$ を発 泡ポリスチレンのトレイ $(200 \times 125 \times 30 \mathrm{~mm})$ に盛り付 け，以下の 3 つの方法で包装した。（A）ストレッチ包装 (対照)はテラオカ製ラッパー $\Lambda \mathrm{W}-2600$ で行った.この 包装は含気纪装ともいわれ，試料は空気に晒されてい る.（B）チャンパー式・真空ガス置換包装：本実験で は，古河製作所(株)製自動真空包装機 FVS Пにガス， ズルを装着した包装機械を用い，チャンバーに直結した 真空ゲージが $76 \mathrm{cmHg}$ に到達後，10秒間真空にし，目 的のガスを充填した（C）横ピロー式・フラッシュガス 置換包装 : 本実験では, (株)川島製作所製 KBF-7000 横 型製袋充嫔機を用い，ガスフラッシュは $60 \mathrm{l} / \mathrm{min} て ゙$ 行った. 包装材料はストレッチ包装には理研ビニル製 ラップフィルム MAT-LNを使用した．本フィルムの特 性は高い透明性で商品価値を上げることにある.ガス置 換包装には昭和電工製 EVOH 系フィルムアロマーVL を使用した，本フィルムの特性は高いガスバリアー性 $\left[10 \mathrm{cc} / \mathrm{m}^{2} \cdot 24 \mathrm{hr} \cdot \operatorname{atm}\left(25^{\circ} \mathrm{C}\right)\right]$, 防湿性 $\left[15 \mathrm{~g} / \mathrm{m}^{2} \cdot 24\right.$ $\left.\mathrm{hr} \cdot \operatorname{atm}\left(37^{\circ} \mathrm{C} \cdot 90 \% \mathrm{RH}\right)\right]$ とチルド温域 $\left(0-3^{\circ} \mathrm{C}\right)$ にお ける防昱性にある(1)。ガス組成は牛肉のガス置換包装に 一般に用いられている $20 \% \mathrm{CO}_{2}+80 \% \mathrm{O}_{2}$ とした(10)12). 各包装試料は $5^{\circ} \mathrm{C}$ で $0,2 ， 4 ， 6 ， 8$ 日間眝蔵後，以下の 分析に供した。

\section{2. 分析方法}

(1) $\mathrm{pH}$ 值

試料挽き肉に倍量の蒸留水を加えホモジナイズし, 得 られたホモジネートにつき日立一堀場 F-7 ss pHメー ターで測定した。

(2) 細菌数

牛肉試料から出来るだけ無菌的に試料を採取し，减菌

Table 1 Changes in $\mathrm{pH}$ of the thin sliced beef during storage

\begin{tabular}{cccc}
\hline \hline \multirow{2}{*}{$\begin{array}{c}\text { Storage } \\
\text { time } \\
\text { (days) }\end{array}$} & Control & $\begin{array}{c}\text { 20\% } \\
\text { Vacuum treatment }\end{array}$ & $\begin{array}{c}20 \% \mathrm{CO}_{2}+80 \% \mathrm{O}_{2} \\
\text { Flush treatment }\end{array}$ \\
\hline 0 & $5.50 \pm 0.04$ & $5.50 \pm 0.04$ & $5.50 \pm 0.04$ \\
2 & $5.49 \pm 0.03$ & $5.49 \pm 0.02$ & $5.47 \pm 0.03$ \\
4 & $5.49 \pm 0.07$ & $5.50 \pm 0.04$ & $5.47 \pm 0.03$ \\
6 & $5.44 \pm 0.10$ & $5.45 \pm 0.09$ & $5.45 \pm 0.09$ \\
8 & $5.58 \pm 0.09^{\text {a** }}$ & $5.41 \pm 0.08^{\mathrm{b}}$ & $5.44 \pm 0.08^{\mathrm{b}}$ \\
\hline
\end{tabular}

* Mean (N=5) \pm Standard deviation

** Within the same horizontal line, values with different superscript are significantly different $(P<0.05)$ 
リン酸䌅衝液を加えホモジナイズした。これを原液とし 混积培養法により生菌数，低温細菌数，大腸菌群の測定 を常法 ${ }^{13)}$ により行った，培地はいずれも日水製薬(株)製 で生菌数には標準寒天培地，低温細菌数には CVT 寒天 培地, 大腸菌群にはデスオキシコーレイト培地である.

(3) MetMb 生成量

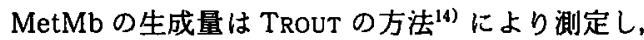
MetMb 生成量パーセントで表した．すなわち，牛肉試 料から筋䈋画分を調製し，得られた筋策画分の 525, $572,730 \mathrm{~nm}$ の吸光度を测定し，その吸光度の值から算 出した.

\section{(4) 脂質酸化}

脂質酸化は試料の TBA number TARLADGIS らの 方法 ${ }^{15)}$ により湘定した. すなわち, 試料から得られた蒸 留液に2-チオバルビッール酸を反応させ，反応液の 538 $\mathrm{nm}$ の吸光度を測定した. 得られた值から, 肉 $1000 \mathrm{~g}$ 中 のマロンアルデヒドmg 数で表した. なお，実験は 5 回 繰り返し，測定結果の統計好理は分散分析を行い，平均 値の差の検定には FISHER の多重比較法を用いた.

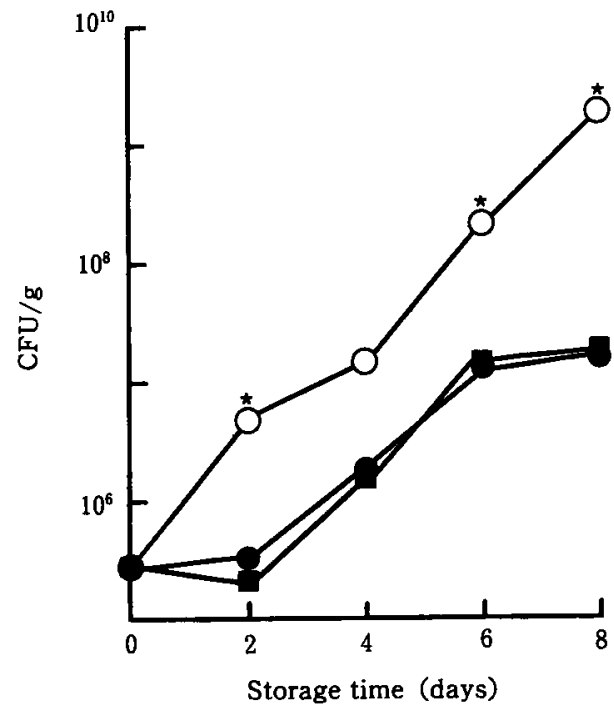

Fig. 1 Changes in viable bacterial count of thin sliced beef during storage

$\mathrm{O}-\mathrm{O}$, control ; $-\mathrm{\square}, 20 \% \mathrm{CO}_{2}+80 \% \mathrm{O}_{2}$ after vacuum treatment ; $-\mathrm{O}, 20 \% \mathrm{CO}_{2}+$ $80 \% \mathrm{O}_{2}$ after flushed with the gas of the same composition

*Significantly different from the vacuum and the flush treatment samples $(P<0.05)$

\section{結果およひ考察}

\section{1. $\mathrm{pH}$ 值の変化}

各包装試料の眝蔵中における $\mathrm{pH}$ 值の変化を Table 1 に示した．眝蔵 6 日目まで，真空ガスの4 日目を除き， すべて 0 日の值より低い值が得られた. しかし，対照は 坾蔵 8 日目には $\mathrm{pH}$ 值が上昇し, 次に述べる生菌数の増 加の結果からも，腐敗現象が始まっていることが示唆さ れた。一方，ガス置換試料は 8 日目まで低い值を保ち， 対照より有意 $(\mathrm{P}<0.05)$ に低いことが認められた. 今 回，その原因の追究は行っていないが，この差異は対照 とガス置換包装試料における細菌叢の違い(6) や炭酸ガ スの試料水分中への溶解 ${ }^{17)}$ などの影整が考えられる. 眝 蔵中における $\mathrm{pH}$ 值の変化に真空とフラッシュガス置换 包装による差異は認められなかった。

\section{2. 細菌数の変化}

各包装試料の眝蔵中における生菌数の変化を Fig. 1 に示した，食肉の場合，生菌数 $10^{7} / \mathrm{g}$ がその賞味期間の 限界で, $10^{8} / \mathrm{g}$ レベルを越えると腐敗現象が生じるとい われている ${ }^{18)}$. 本実験では, 対照で 3 日目，ガス置換包

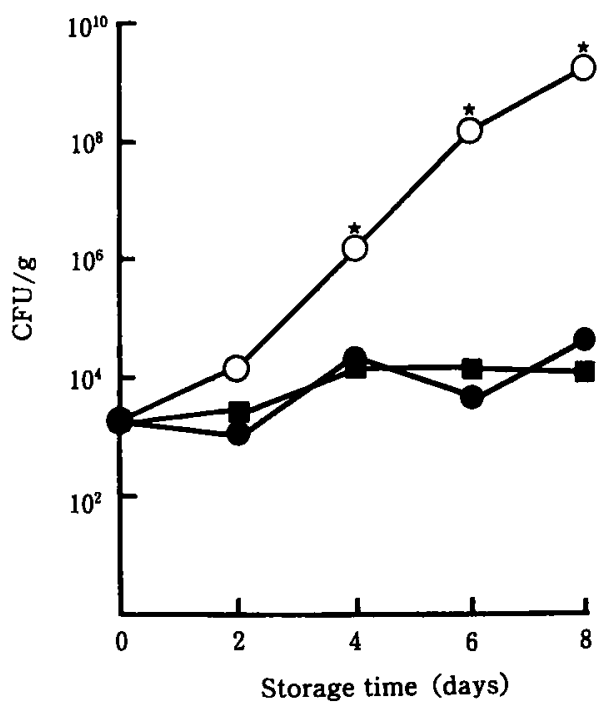

Fig. 2 Changes in psychrotrophic bacteria of thin sliced beef during storage

$\mathrm{O}-\mathrm{O}$, control ; $-\mathrm{D}, 20 \% \mathrm{CO}_{2}+80 \% \mathrm{O}_{2}$ after vacuum treatment; - $-20 \% \mathrm{CO}_{2}+$ $80 \% \mathrm{O}_{2}$ after flushed with the gas of the same composition

*Significantly different from the vacuum and the flush treatment samples $(P<0.05)$ 
装試料では 6 日目までは $10^{7} / g$ を保持したが，対照では 6 日目には $10^{8} / \mathrm{g}$ に達した。詝蔵 4 日目を除き，ガス置 换武料においてすべて対照より有意 $(\mathrm{P}<0.05)$ に低い值 が認められた。 低温細菌数と大腸菌群の変化は Figs. 2 と3に示した. その結果, 低温細菌数と大腸菌群とあに ガス置換包装試料では盯葴中低く抑制されたが，対照で はほ值線的に増加する傾向が認められた．特に，低温 細菌の增殖はガス置換包装試料に扰いて著しく抑制され た.この原因は，これまで報告(6) 8) されているようにグ ラム陰性菌に対する炭酸ガスの静菌効果が発揮されたも のと思われる. 細菌数の変化に真空とフラッシュガス置 換包装による差異はいずれも諰められなかった。

\section{MetMb 生成量の変化}

各包装試料の詝蔵中における MetMb 生成量の変化を Fig. 4 に示した，MetMb生成量は対照で 3 日目，真空 ガス置換包装試料では 5 日目, フラッシュガス置換包装 試料で 6 日目で約 $20 \%$ に達した. 肉塊表面の MetMb 生成量 20\% 程度が色調の面からの棚持ち寿命の限界之 いわれている ${ }^{19)}$. 先に，横山婂は屠殺 10 日後のホルス タイン去勢牛肉を小売用に本実験と同一のガス組成で真

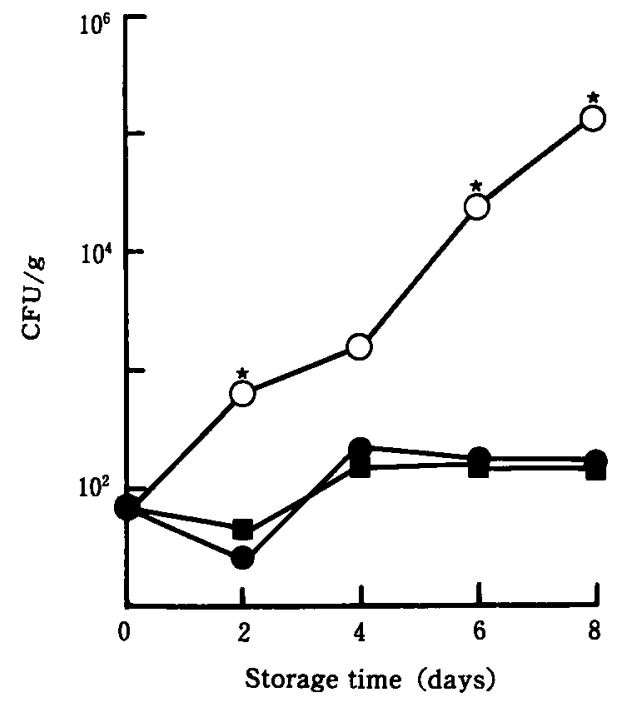

Fig. 3 Changes in coliform group of thin sliced beef during storage

$\mathrm{O}-\mathrm{O}$, control; $\mathbf{\square}, 20 \% \mathrm{CO}_{2}+80 \% \mathrm{O}_{2}$ after vacuum treatment; - $20 \% \mathrm{CO}_{2}+$ $80 \% \mathrm{O}_{2}$ after flushed with the gas of the same composition

*Significantly different from the vacuum and the flush treatment samples $(P<0.05)$
空ガス置換包装とストレッチ包装 (対照) を行い, $5^{\circ} \mathrm{C} に$ 眝蔵し, 肉色の評価を行った。 その結果, 対照は眝蔵 3 日目頃加肉色が急速に变化したのに対し, 真空がス置 換包装試料では眝蔵 7 日目頃から肉色の変化か認められ たと報告し，今回の結果とほぼ一致した。ささらに, OKAYAMA ${ }^{21)}$ は牛ロース（厚さ $1.5 \mathrm{~cm}$ )を $4^{\circ} \mathrm{C}$, 本実験之 同一のガス組成の気相下で眝蔵し，MetMb生成量は 13 日間, $20 \%$ 以下であったと報告した. 今回の結果との差 異は屠殺からの日数, 試料の部位・厚さ, 眝蔵温度など の条件の違いに起因しているものと考えられる，眝蔵 6 日目において MetMb 生成量は対照の $52.1 \% \pm 23.2$ に対

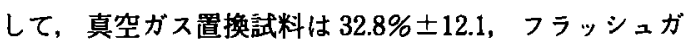
ス直換試料は $22.4 \% \pm 8.3$ を示した. 対照と真空ガス試 料との間に有意差は認められなかったが，対照とフラッ シュガス試料の間には有意差が認められた。その原团に ついて今回追究していないが, 真空脱気時に牛肉試料表 面に内部の肉汁が渗出するとの観察もあり, それらのこ とが Mbをメト化しやすい条件を引き起こしているの かすしれない，さらに，メト化には酸素分圧が大きく影 響する ${ }^{22)}$ ので, 真空脱気処理が牛肉試料の酸素分圧に何

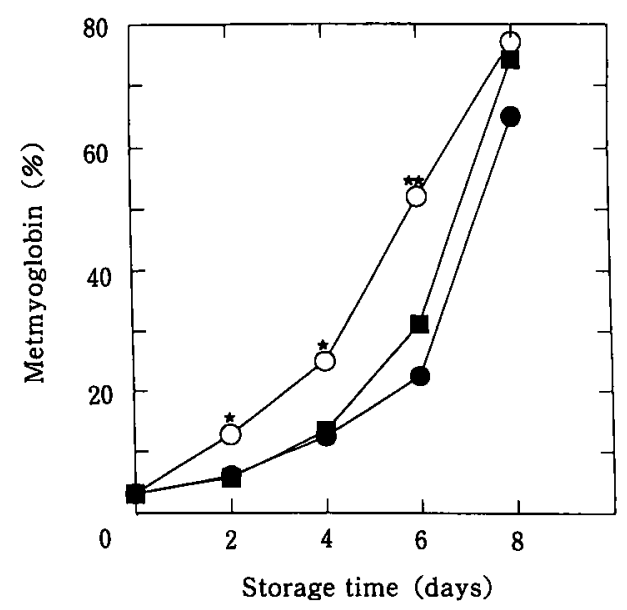

Fig. 4 Changes in metmyoglobin formation of thin sliced beef during storage

O-O, control; - $-20 \% \mathrm{CO}_{2}+80 \% \mathrm{O}_{2}$ after vacuum treatment; - $-20 \% \mathrm{CO}_{2}+$ $80 \% \mathrm{O}_{2}$ after flushed with the gas of the same composition

*Significantly different from the vacuum and the flush treatment samples $(P<0.05)$

**Significantly different from the flush treatment sample $(\mathrm{P}<0.05)$ 
等かの影輞を及ばしたのかもしれない，さらに，眝葴 0 日と8日目の筋漿画分の吸収スペクトルの結果を Fig. 5 に示した．眝葴 0 日試料において典型的な Mbのスペク

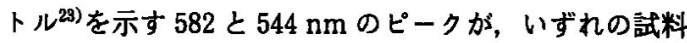
においてあ眝蔵 8 日目にはかなり減少した。一方， 630 $\mathrm{nm}$ 付近の吸光度は眝蔵日数の経過に伴って増加し，眝 蔵中に $\mathrm{MbO}_{2}$ の一部が酸化し MetMbを生成したこと

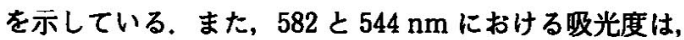
いずれも真空ガス置換包装よりフラッシュガス置換包装
の試料の方が值は高く $\mathrm{MbO}_{2}$ の酸化は抑制されたこと を示している．これらの結果から，MetMb生成量は真 空とフラッシュガス置換包装によって量いが生じる可能 性が示唆された.

\section{4. 脂䨘酸化の変化}

各包装試料の詝葴中における TBA number の変化を Fig. 6 に示した. TBA number 值は眝葴期間中, 高酸素 条件下にあるガス置換包装試料において対照より平均値 で高い値が得られた.しかし, 眝蔵 6 日目における TBA

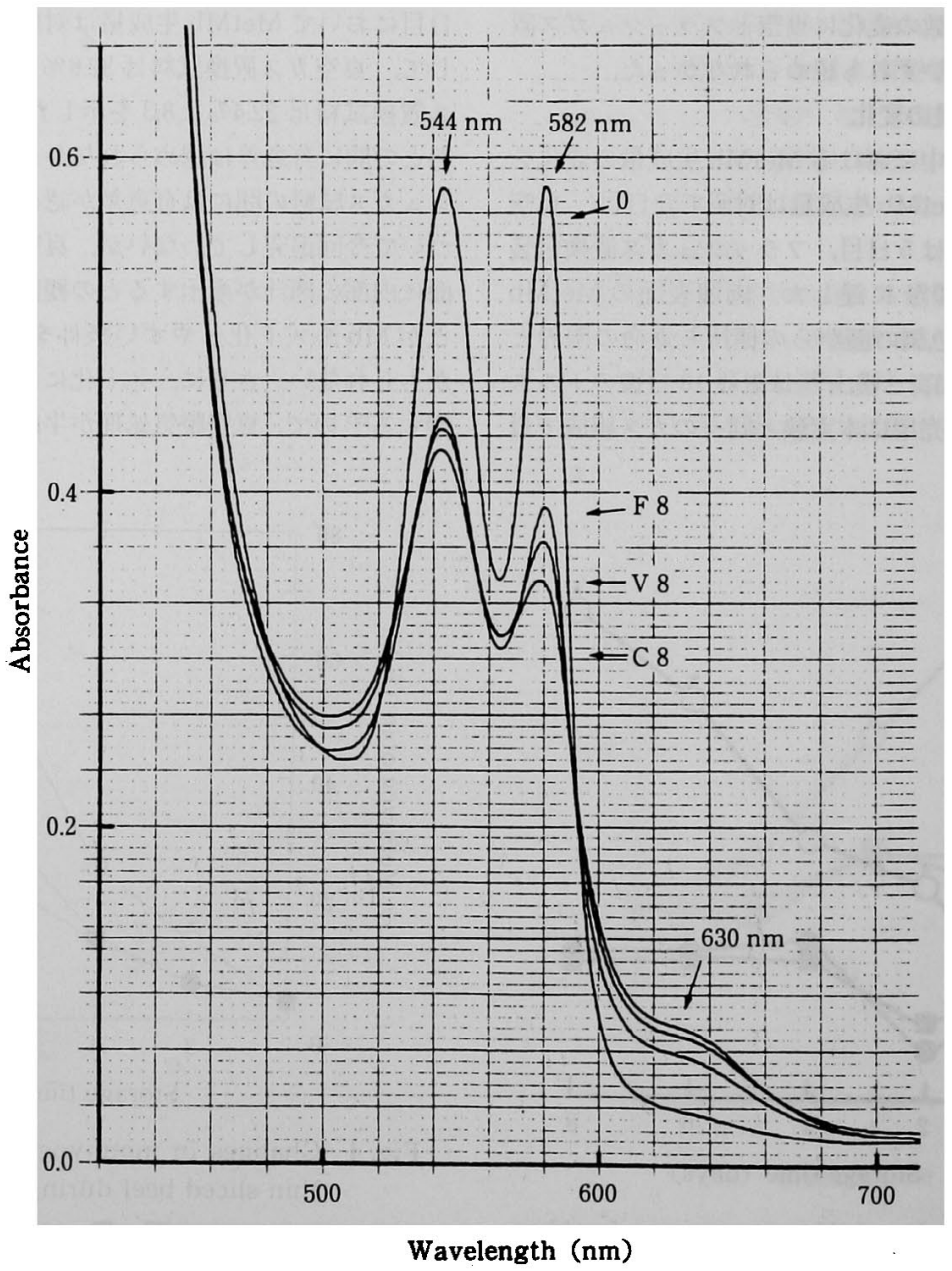

Fig. 5 Absorption spectra of myoglobin from thin sliced beef during storage

0,0 day sample; $\mathrm{C} 8$, Control after 8 days of storage; $\mathrm{V} 8$, $20 \% \mathrm{CO}_{2}+80 \% \mathrm{O}_{2}$ after vacuum treatment after 8 days of storage ; F8, 20\% $\mathrm{CO}_{2}+80 \% \mathrm{O}_{2}$ after flushed with the gas of the same composition after 8 days of storage 


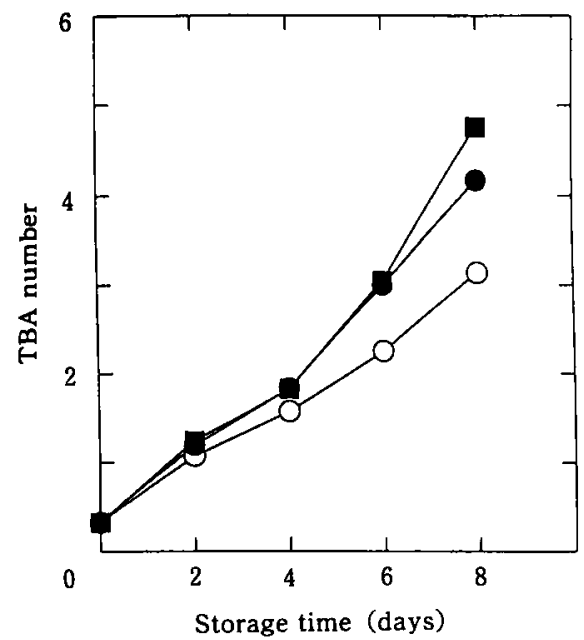

Fig. 6 Changes in TBA number (malonaldehyde $\mathrm{mg} / 1000 \mathrm{~g}$ meat) of thin sliced beef during storage

$\mathrm{O}-\mathrm{O}$, control; $\mathbf{\square}-\mathbf{\square}, 20 \% \mathrm{CO}_{2}+80 \% \mathrm{O}_{2}$ after vacuum treatment :-0. $20 \% \mathrm{CO}_{2}+$ $80 \% \mathrm{O}_{2}$ after flushed with the gas of the same composition

number 值は対照の $2.2 \pm 0.9$ に対して両ガス置換包装試 料では $3.0 \pm 1.3,8$ 日目では対照の $3.1 \pm 1.4$ に対して，真 空ガス置換包装の試料は $4.7 \pm 2.0$, フラッシュガス置換 包䒾の試料は $4.2 \pm 1.1$ であった。 そして，眝蔵期間中す へての試料間に有意差は認められなかった。 ORDONEZ and LEDWARD ${ }^{24)}$ は TBA number 值が約 5.0 に達する と明らかに酸敗真を感じると報告した。ささらに，永松と 日比 ${ }^{10)}$ は $80 \% \mathrm{O}_{2}$ 気相下で牛脂の過酸化物価を測定し, 牛脂の酸化は高洤度酸素条件下でも特に促進されなかっ たと報告している．本実験条件下においてもガス置換包 装試料において眝蔵 6 日目で TBA number 值は 3.0 で 酸敗臭は大きな問題とはならなかった。脂質酸化におい て真空とフラッシュガス置換包装による差異は認められ なかった.

なお，本実験と同一条件下で行われた・スライス牛肉 の原線維の小片化，筋肉蛋白質の抽出性おょび LDH 活性に及ぼすガス置換包装の影䭗”については第 2 報で 较告する。

\section{要約}

一般市場にすでに流通しているのと同一のガス置換包 装条件下で, スライス牛肉の pH 值, 細菌数, MetMb生 成量および脂質酸化に及ぼす真空とフラッシュガス置換 包装の影響につき検討することを目的とした，スライス 牛肉を（A）ストレッ千包装 (対照)，(B） $20 \% \mathrm{CO}_{2}+$ $80 \% \mathrm{O}_{2}$ 真空ガス置換包装， (C) $20 \% \mathrm{CO}_{2}+80 \% \quad \mathrm{O}_{2}$ ᄀ ラッシュガス置換包装し， $5^{\circ} \mathrm{C}$ に眝蔵した。， $0 ， 4 ， 6$ ， 8 日後, $\mathrm{pH}$ 值, 細菌数, MetMb 生成量および脂質酸化 (TBA number) につき分析した. その結果，1) pH 值は 対照では眝蔵 8 日目には上昇したが，(B)上（C) 試料は 低い $\mathrm{pH}$ 值を保持した. 2) 生菌数, 低温細菌数および大 腸菌群ともに（B）と（C）のガス置換包装試料では対照 に比べて低い值が得られた．3）MetMb 生成量は対照, （B）および（C）試料においていずれあ貯蔵 3，5 と6日 後で $20 \%$ に達した. 眝蔵 6 日目, MetMb 生成量は対照 と（C）試料のみに有意差が認められ, 真空とフラッシュ ガス置換包装の差異が生じる可能性が示唆された. 4) TBA number は盯蔵期間中，高酸素条件下のガス置換 包装試料にわいて対照より高い平均値が得られたが, 眝 蔵 6 日後においても3 程度であった。二つの異なった方 法でガス置換包装したスライス牛肉の $\mathrm{pH}$ 值, 細菌数, 脂質酸化に有意な差異は認められなかったが, MetMb 生成量の一部に違いが生じる可能性が示唆された。

\section{文献}

1）横山理雄：食品と包装, 横山理雄 - 石谷孝佑編 (医歯薬出版, 東京)，p. 302 (1982).

2) Buys, E.M., KRuger, J. and NoRTJE, G.L. : Meat Sci., 36, 293 (1949).

3) Daun, H., Solberg, M., Franke, W. and Gilbert, S. : J. Food Sci., 36, 1011 (1971).

4) TAYlor, A.A. and Macdougall, D.B. : J. Food Technol., 8, 453 (1973).

5) BARTKOWSKI, L., DRYden, F.D. and MARChELlo, J.A. : J. Food Prot., 45, 41 (1982).

6) Huffman, D.L., Davis, K.A., MARPLE, D.N. and McGuire, J.A. : J. Food Sci., 40, 1229 (1975).

7) GeE, D.L. and Brown, W.D. : Meat Sci., 5, 215 (1980-81).

8) Spahl, A., Reineccius, G. and Tatini, S. : J. Food Prot., 44, 670 (1981).

9）富岡芳彦・安田松夫 -土屋恵美子 - 横山理雄 : 日 食工誌, 30, 25 (1983).

10）永松幹晴・日比 洋: 食肉界, 20, 75 (1983).

11）海沼祐治：包装技術, 30，1123（1992）. 
12) LAWRIE, R. : Developments in Meat Science-3, (Elsevier Applied Sci. Pub., London and New York), p. 104 (1985).

13）日本莧学会編 : 衛生試験法 - 注解, (金原出版, 東 京), p. 107 (1980).

14) Trout, G.R. : Meat Sci., 28, 203 (1990).

15) Tarladgis, B.G., WatTs, B.M. and Younathan, M.T. Jr. : J. Am. Oil Chem. Soc., 37, 44 (1960).

16）萩原博和・安田松夫・里見弘治・横山理雄・矢野 信礼：日本包装学会誌，2，211（1993）.

17) Ledward, D.A. : J. Food Sci., 35, 33 (1970).

18) Kilsby, D.C. : Meat Microbilogy (Brown, M.H., ed. Applied Sci. Pub., England), p. 378 (1982).

19) O'Keeffe, M. and Hood, D.E. : Meat Sci., 7, 209 (1982).

20) 横山理雄 : 肉の科学, 28, 175 (1987).

21) OKayama, T. : Meat Sci., 19, 179 (1987).

22) BRooks, J. : Food Res., 3, 75 (1938).

23) Bowen, W.J. : J. Biol. Chem., 179, 235 (1949).

24) Ordonez, J.A. and Ledward, D.A. : Meat Sci., 1, 41 (1977).

（平成 6 年 8 月 3 日受理） 